\title{
Novel Media for Lipid Production of Chlorococcum oleofaciens : A RSM Approach
}

\author{
J. Mercy Nisha PAULINE', Anant ACHARY2 \\ ${ }^{1}$ Department of Industrial Biotechnology, Government College of Technology, Coimbatore-641013, Tamil Nadu, India \\ ${ }^{2}$ Department of Biotechnology, Kamaraj College of Engineering \& Technology, K. Vellakulam Madurai - 625701, Tamil Nadu, \\ India
}

\begin{abstract}
The algal medium was optimized to increase the biomass and lipid production of Chlorococcum oleofaciens. The significant variables were screened and chosen from previously reported algal culture media using Plackett Burman Design (PBD). Optimization of the significant variables were performed using central composite design. The Pareto chart for PBD revealed that the salts such as sodium bicarbonate, sodium nitrate, potassium nitrate and ferrous sulphate had enhanced the biomass and lipid production. The variables and its effect on the responses were further studied by central composite design (CCD). A new medium was formulated based on the response surface methodology. The predicted concentration of $\mathrm{NaHCO}_{3}, \mathrm{NaNO}_{3}, \mathrm{KNO}_{3}, \mathrm{MgSO}_{4} .7 \mathrm{H}_{2} \mathrm{O}$ were found to be $6.75 \mathrm{~g} / \mathrm{L}, 0.75 \mathrm{~g} / \mathrm{L}, 1.88 \mathrm{~g} / \mathrm{L}$ and 0.35 $\mathrm{g} / \mathrm{L}$ respectively. The actual and the predicted total lipid yield for the optimized media was around $0.74 \mathrm{~g} / \mathrm{L}$ and $0.78 \mathrm{~g} / \mathrm{L}$ respectively. The optimal medium has been named as AM medium. Growth and the lipid yields of $C$. oleofaciens were found higher in AM medium. The specific growth rates of $C$. oleofaciens in AM and CFTRI media were found to be 0.14 day $^{-1}$ and 0.19 day $^{-1}$ respectively. The biomass produced by the optimized AM medium was found to be 2.7 times greater compared to the CFTRI medium. The lipid was extracted and GC-MS was performed which revealed that the fatty acids were predominantly of the class $\mathrm{C} 15: 0, \mathrm{C} 18: 0, \mathrm{C} 16: 0$ and $\mathrm{C} 12: 0$. It is concluded that besides lipid content, AM medium increased the cell number leading to the increase in biomass.
\end{abstract}

Key words: Biomass; Central composite design; Lipid; Medium optimization; Plackett Burman Design; AM medium.

Abbreviations: PBD - Plackett Burman design; CCD - central composite design; AM - Anant Mercy

\section{INTRODUCTION}

Oil and fuel resources have dominated the world after the Second World War. As global population explodes to over 7.7 billion and industrial revolution flourishes, the demand for fuel has been ever increasing. The fuel

Address for correspondence: Anant Achary, Department of Industrial Biotechnology, Government College of Technology, Coimbatore-641013, Tamil Nadu, India; E-mail: achyanant@yahoo.com resources also get depleted causing a drastic increase in the cost of the fuel demanding the search of alternate and renewable energy resources (Tiwari et al. 2007) Renewable energy sources like wind energy, geothermal energy, solar energy, tidal energy, biofuels, etc., contributes to only $8.4 \%$ of global productivity. One of the promising and pioneer green energy resources is biomass such as corn, palm, molasses, sugar cane bagasse which has been identified as the first generation biofuel (Van der Laaka et al. 2007). Besides, lignocel- 


\section{Graphical abstract}

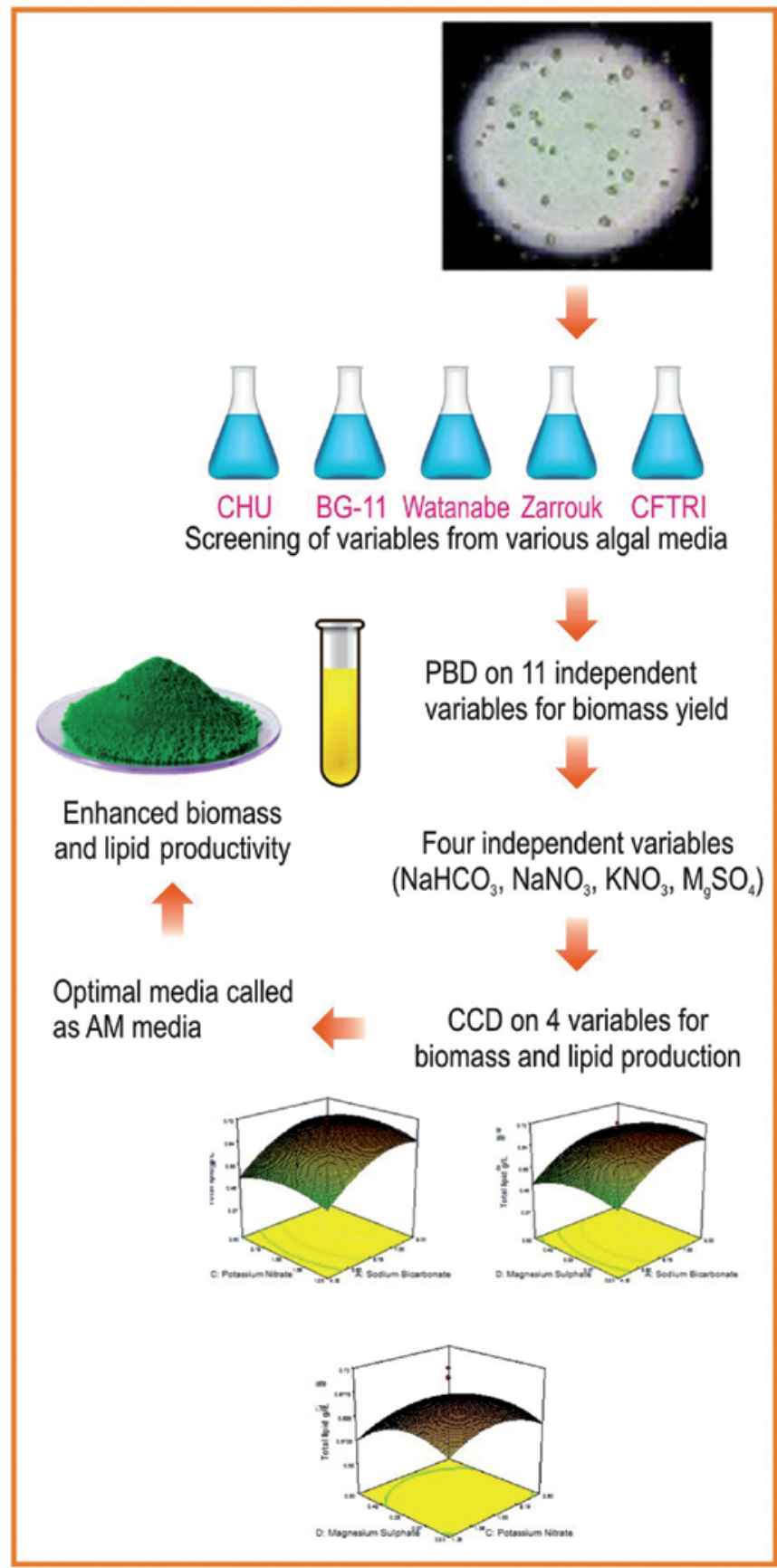

lulosic wastes, plants such as jatropha, sunflower, soya bean etc., are being widely used due to the accumulation of lipid in their seeds and thus forms the second generation of biofuels (Liu et al. 2008). The search for an alternate which does not serve as a food material has paved way for the exploitation of algae which is the third generation of biofuel. The cultivation of micro- algae has received renewed attention on account of its ability to fix $\mathrm{CO}_{2}$ upon exposure to sunlight (Wu et al. 2006). This $\mathrm{CO}_{2}$ mitigation in these cells results in the formation and accumulation of lipids. Algae synthesize fatty acids into glycerol-based membrane lipids, which constitute about $20 \%$ of its dry cell weight (DCW). Under unfavorable environmental or stress condition, algae alter their lipid synthesis pathways towards the formation and accumulation of neutral lipids (20-50\% DCW), which are in the form of triacylglycerol (TAG). TAGs serve primarily as a storage form of carbon and energy (Qiang Hu et al. 2008; Liu J 2011). After extracting the lipid from microalgae, the remaining biomass portion could be used as a high protein feed for livestock. Therefore, the commercial cultivation of microalgal biomass is a promising method of producing a renewable feedstock for a wide variety of highvalue biofuels which also includes methane produced by anaerobic digestion of biomass (Golueke CG et al. 1957), biodiesel derived from algal oil (Shay EG 1993), biohydrogen (Ghirardi ML et al. 2000) and bioethanol (Ramachandran Sivaramakrishnan et al. 2018).

Though algae serve as promising feedstock for biodiesel production, large scale cultivation of algae is still not a viable process due to the high cost associated with the biomass production. Algal medium and other parameters have been optimized but it is being widely directed to increase the protein content, pigments such as xanthin, carotenoids (Franklin SE 2004), lutein (Baldo F et al. 2011) etc., which are of high nutrient and commercial value. For the usage of algae as a source of fuel, production of high biomass is needed. The medium should favour the biomass production over the other metabolites. The biomass obtained initially can further be made to accumulate more lipid by various strategies like heterotrophic cultivation (Wu Q et al. 2006), nitrogen deprivation (Tornabene TG 1983) and by double $\mathrm{CO}_{2}$ fixation or two stage cultivation (Wei Xiong et al. 2010).

Simple, defined media composed of inorganic salts are widely being used for the cultivation of algae as it is cost effective. To formulate a new optimized medium for algae which will favour the production of biomass, various commonly used algal media such as Zarrouk medium (Claude Zarrouk 1966), BG-11 (Allen MM et al. 1968), Bold's Basal medium (Bischoff HW et al. 1963), Walne's medium (Walne PR 1970), Chu-10 medium (Stein J 1973) and CFTRI medium (Venkatraman LV 1985) were chosen for the selection of variables. All these media contained nutrient like $\mathrm{C}, \mathrm{N}, \mathrm{P}, \mathrm{K}, \mathrm{Mg}, \mathrm{Ca}$, 
$\mathrm{S}, \mathrm{Fe}, \mathrm{Cu}, \mathrm{Mn}$ and $\mathrm{Zn}$ which were added in the form of inorganic salts.

Algae rich in lipid content and those which produce substantial amount of TAG or oil are said to be oleaginous in nature and thus it could be employed as cell factories to produce oils and other lipids for biofuels and other biomaterials (Qiang Hu et al. 2008). Fatty acids after esterification with alkali and methanol produce biodiesel. Transesterification is a chemical process where the free fatty acids of oil are esterified to monoalkyl esters of long-chain fatty acids by short-chain alcohols to produce fatty acid methyl esters (FAMEs) and fatty acid ethyl esters (FAEEs) (Marchetti JM 2007).

Environmental conditions including nutrient composition and physiological state of the cells affect the biomass and the degree of saturation of the lipids (Cho et al. 2015). At this juncture, the present study aims at optimizing the algal media to enhance the biomass and lipid production of $C$. oleofaciens. Although several studies on medium optimization towards biomass and lipid production have been carried out, these studies were not performed at such high carbon and nitrogen sources. The range of concentration of the salts chosen for PBD and CCD is given in tables 1 and 2. The selection of variables for the present study was done by Plackett Burman design followed by the optimization of the significant variables towards algal biomass and lipid productivity using Central Composite Design to study the interaction among the variables. Eleven variables were chosen for the Plackett Burman Design (PBD). The lipid was also analyzed at various stages of growth. The optimized media was compared for biomass production with the renowned CFTRI media.

\section{MATERIALS AND METHODS}

\section{Organism}

Fresh water microalgae Chlorococcum oleofaciens culture obtained from Vivekananda Institute of Algal Technology (VIAT), Chennai was isolated from the temple ponds of Mylapore. The microscopic studies suggested that the cellular shape of the organism appeared spherical in shape. It was found to be a highly motile unicellular microalgae. The cells appeared green with its vesicles clearly visible inside.

\section{Medium Preparation}

The $C$. oleofaciens was subcultured and maintained in CFTRI medium (Venkatraman LV et al. 1985). This medium was chosen due to the high concentration of nitrogen. It also consisted of other salts that are widely used in the algal media such as: Sodium bicar- bonate $4.5 \mathrm{~g} / \mathrm{L}$, di potassium hydrogen phosphate $0.5 \mathrm{~g} / \mathrm{L}$, sodium nitrate $1.5 \mathrm{~g} / \mathrm{L}$, potassium sulphate $1 \mathrm{~g} / \mathrm{L}$, sodium chloride $1 \mathrm{~g} / \mathrm{L}$, magnesium sulphate heptahydrate $0.2 \mathrm{~g} / \mathrm{L}$, anhydrous calcium chloride $0.04 \mathrm{~g} / \mathrm{L}$, potassium di hydrogen phosphate $1.25 \mathrm{~g} / \mathrm{L}$, anhydrous ferrous sulphate $17.9 \mathrm{mg} / \mathrm{L}$ and EDTA $14.8 \mathrm{mg} / \mathrm{L}$. The $\mathrm{pH}$ of the medium was found to be 8.8 .

\section{Culture conditions}

$250 \mathrm{ml}$ Erlenmeyer flasks containing $100 \mathrm{ml}$ of culture were maintained in an orbital shaker at $28^{\circ} \mathrm{C}$ at $100 \mathrm{rpm}$ illuminated with white light of intensity 1200 lux (Ramachandran Sivaramakrishnan et al. 2017). During the experiment, the cultures were exposed to $12 \mathrm{~h}$ light and $12 \mathrm{~h}$ dark. Growth was monitored by cell count using haemocytometer (Martinez MR 1975).

\section{Estimation of biomass}

Filter $5 \mathrm{ml}$ of the culture of $C$. oleofaciens through pre weighed cellulose acetate membrane of pore size $0.2 \mu \mathrm{m}$ under vacuum pressure. It was dried for $5 \mathrm{~h}$ in a hot air oven at a temperature of $50^{\circ} \mathrm{C}$. Biomass was estimated on dry weight basis by the difference in the weight of the membranes. (Illman $\mathrm{M}$ et al. 2005). The growth rate was determined by the following formula (Guillard et al. 1962):

$$
\mu=\ln \left(\mathrm{N}_{\mathrm{t}}-\mathrm{N}_{0}\right) / \mathrm{T}_{\mathrm{t}}-\mathrm{T}_{0}
$$

where $\mathrm{N}_{\mathrm{t}}$ and $\mathrm{N}_{0}$ - cell number at time $\mathrm{T}_{\mathrm{t}}$ and $\mathrm{T}_{0}$.

\section{Extraction of lipid}

Approximately, $1 \mathrm{~g}$ of the wet biomass was taken in a conical flask to which $4 \mathrm{ml}$ of hexane was added. The flask was kept in a shaker at constant stirring overnight until the separation of layers was visible and the excess solvent was removed by rotary evaporator. The organic layer containing the extracted lipid was separated and estimated using the formula (Gutierrez LF et al. 2008):

Lipid yield $(\%)=\frac{\text { Weight of the lipid extract }(\mathrm{g}) \times 100}{\text { Weight of the dry algal biomass }(\mathrm{g})}$

\section{Estimation of total lipids}

The dry biomass was treated with hexane for extracting all the transesterifiable lipid which mainly consists of neutral lipids including TAG, DAG, cholesterol etc. Lipid content was calculated on weight basis. Lipid production was calculated using the following relation:

Total lipid production $=\mathrm{m} \times \mathrm{L}($ Fangfang Yang et al. 2014)

where $\mathrm{m}$ - biomass concentration $(\mathrm{g} / \mathrm{L})$

$\mathrm{L}$ - Lipid yield (\%)

\section{Analysis of Lipids by GC/MS}

The lipid extracted by gravimetric method was further analyzed by gas chromatography (GCMS-QP-2010plus, SHIMADZU) using the capillary Rtx-5MS column of dimension $30 \mathrm{~m} \times 0.32 \mathrm{~mm}$ and $0.5 \mu \mathrm{m}$ coating thickness (J\&W, Scientific, Agilent, Waldbronn). Helium was used as the carrier gas with a flowrate of $41.0 \mathrm{ml} / \mathrm{min}$. The temperature gradient was maintained at 0 to $150^{\circ} \mathrm{C}$ for $0 \mathrm{~min}$, 150 to $200^{\circ} \mathrm{C}$ for $10 \mathrm{~min}, 200$ to $270^{\circ} \mathrm{C}$ for $10 \mathrm{~min}$. Tripentade- 
Table 1. Range of variables for PBD

\begin{tabular}{llccc}
\hline \multirow{2}{*}{$\begin{array}{l}\text { Code } \\
\text { Independent } \\
\text { Variables }\end{array}$} & \multicolumn{3}{c}{ Levels } \\
\cline { 3 - 5 } & & +1 & 0 & -1 \\
\hline $\mathrm{A}$ & $\mathrm{NaHCO}_{3}(\mathrm{~g} / \mathrm{L})$ & 4.5 & 3.375 & 2.25 \\
$\mathrm{~B}$ & $\mathrm{~K}_{2} \mathrm{HPO}_{4}(\mathrm{~g} / \mathrm{L})$ & 0.5 & 0.375 & 0.25 \\
$\mathrm{C}$ & $\mathrm{NaNO}_{3}(\mathrm{~g} / \mathrm{L})$ & 1.5 & 1.125 & 0.75 \\
$\mathrm{D}$ & $\mathrm{K}_{2} \mathrm{SO}_{4}(\mathrm{~g} / \mathrm{L})$ & 1 & 0.75 & 0.5 \\
$\mathrm{E}$ & $\mathrm{NaCl}_{(\mathrm{g} / \mathrm{L})}$ & 1 & 0.75 & 0.5 \\
$\mathrm{~F}$ & $\mathrm{MgSO}_{4} \cdot 7 \mathrm{H} / \mathrm{O}(\mathrm{g} / \mathrm{L})$ & 0.2 & 0.15 & 0.1 \\
$\mathrm{G}$ & $\mathrm{CaCl}_{2}(\mathrm{~g} / \mathrm{L})$ & 0.02 & 0.03 & 0.04 \\
$\mathrm{H}$ & $\mathrm{KH}_{2} \mathrm{PO}_{4}(\mathrm{~g} / \mathrm{L})$ & 1.25 & 0.9375 & 0.625 \\
$\mathrm{I}$ & $\mathrm{KNO}_{3}(\mathrm{~g} / \mathrm{L})$ & 1.25 & 0.9375 & 0.625 \\
$\mathrm{~J}$ & $\mathrm{FeSO}_{4}(\mathrm{mg} / \mathrm{L})$ & 17.9 & 13.43 & 8.9 \\
$\mathrm{~K}$ & $\mathrm{EDTA}_{(\mathrm{mg} / \mathrm{L})}$ & 14.8 & 1.11 & 7.4 \\
\hline
\end{tabular}

Table 2. Range of variables for CCD

\begin{tabular}{llccccc}
\hline \multirow{2}{*}{$\begin{array}{l}\text { Code } \\
\text { Variables }\end{array}$} & \multicolumn{5}{c}{ Levels } \\
\cline { 3 - 7 } & & -2 & +2 & 0 & +1 & -1 \\
\hline $\mathrm{A}$ & $\mathrm{NaHCO}_{3}(\mathrm{~g} / \mathrm{L})$ & 2.25 & 11.25 & 6.75 & 9 & 4.5 \\
$\mathrm{~B}$ & $\mathrm{NaNO}_{3}(\mathrm{~g} / \mathrm{L})$ & 0.75 & 3.75 & 2.25 & 3 & 1.5 \\
$\mathrm{C}$ & $\mathrm{KNO}_{3}(\mathrm{~g} / \mathrm{L})$ & 0.625 & 3.125 & 1.875 & 2.5 & 1.25 \\
$\mathrm{D}$ & $\mathrm{MgSO}_{4}\left(7 \mathrm{H}_{2} \mathrm{O}(\mathrm{g} / \mathrm{L})\right.$ & 0.05 & 0.65 & 0.35 & 0.5 & 0.2 \\
\hline
\end{tabular}

canoate was added as the standard to the sample for quantification. The lipids were identified based on the retention time of the corresponding peaks in the standard lipid. Mix C4-C24 (Sigma, München), which was injected before every 50th run (Kandhro et al. 2008).

\section{Software used}

Design Expert Version 8.0.5, Stat - Ease Inc. was used for the design and analysis of the experiments by Central Composite Design.

\section{Selection of Significant Media Components by PBD}

The PB (Plackett RL et al. 1946) design was used in this study to evaluate the effects of 11 independent variables within the region of three- dimensional observation space to design a minimal number of experimental runs. From extensive research of literature, algal media like CFTRI medium, BG-11 medium, Zarrouk medium, Chu-10 medium and bold basal media were considered for this study. Depending on the frequency at which the salts were predominantly used and the influence of medium components on the growth of algae, 11 medium components were selected as variables to study their interactions and its augmented effect. These salts were also found to be predominantly used in most of the algal media formulations. The optimization was carried out by using the experimental design of 15 runs given by Stat-Ease software. The list of the salts and the range at which it was taken is shown in the table 1.

The biomass concentration expressed as $\mathrm{g} / \mathrm{L}$ was selected as the response variable which was subjected to analysis of variance (ANOVA). Pareto chart was used to select the influencing variables.

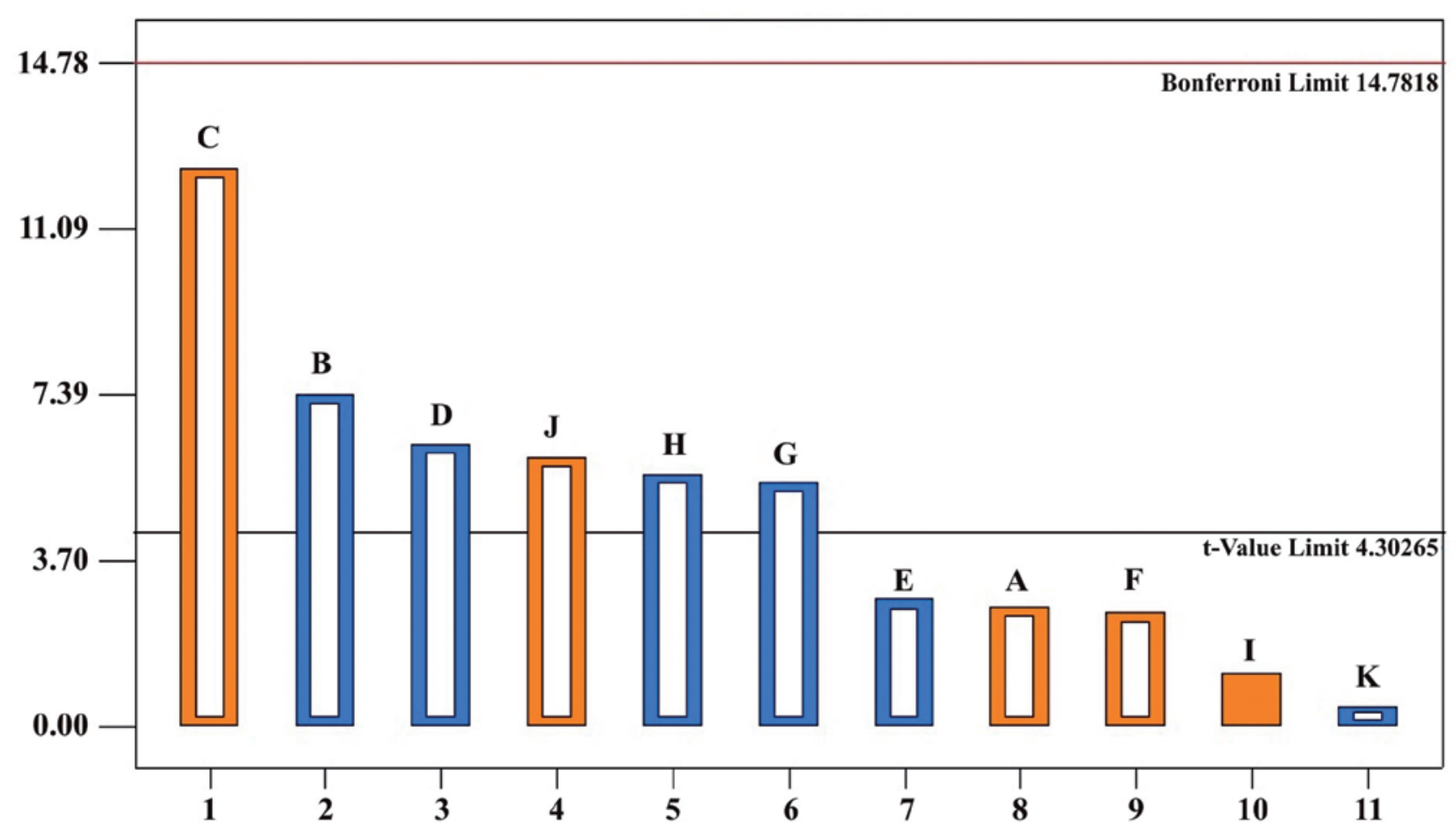

Fig. 1. Effect of variables on Biomass Production - Pareto Chart 
Table 3. Analysis of Variance (ANOVA) for Placket Burman Design

\begin{tabular}{|c|c|c|c|c|c|}
\hline Source & $\begin{array}{l}\text { Sum of } \\
\text { Squares }\end{array}$ & Df & $\begin{array}{c}\text { Mean } \\
\text { Square }\end{array}$ & F value & $\begin{array}{l}\text { p-value } \\
\text { Prob }>\text { F }\end{array}$ \\
\hline Model & 1.96 & 10 & 0.2 & 36.60 & 0.0269 \\
\hline A-Sodium Bicarbonate & 0.038 & 1 & 0.038 & 7.11 & 0.1165 \\
\hline B-Di Potassium Hydrogen Phosphate & 0.29 & 1 & 0.29 & 54.71 & 0.0178 \\
\hline C-Sodium nitrate & 0.82 & 1 & 0.82 & 153.80 & 0.0064 \\
\hline D-Potassium Sulphate & 0.21 & 1 & 0.21 & 39.28 & 0.0245 \\
\hline F-Magnesium Sulphate heptahydrate & 0.034 & 1 & 0.034 & 6.38 & 0.1275 \\
\hline G-Calcium Chloride & 0.16 & 1 & 0.16 & 29.32 & 0.0325 \\
\hline H-Potassium di hydrogen Phosphate & 0.17 & 1 & 0.17 & 31.41 & 0.0304 \\
\hline I-Potassium Nitrate & 0.19 & 1 & 0.19 & 35.83 & 0.0268 \\
\hline J-Ferrous Solution & 0.0009774 & 1 & 0.0009774 & 0.18 & 0.7106 \\
\hline K-EDTA solution & 0.043 & 1 & 0.043 & 7.95 & 0.1061 \\
\hline Curvature & 0.25 & 1 & 0.25 & 47.63 & 0.0204 \\
\hline Residual & 0.011 & 2 & 0.005348 & & \\
\hline Lack of Fit & 0.007415 & 1 & 0.007415 & 2.26 & 0.3737 \\
\hline Pure Error & 0.003280 & 1 & 0.003280 & & \\
\hline Cor Total & 2.22 & 13 & & & \\
\hline
\end{tabular}

\section{Optimization by Response Surface Methodology}

The optimization of biomass production was further refined by using central composite design (CCD) of Response Surface Methodology. The CCD is a statistical experimental design (Table 2) where each numeric factor is varied over 5 levels: alpha points $(-2,+2), 1$ factor $(-1,+1)$ and one center point resulting in 30 experiments. 4 significant variables of PBD were chosen for the experiment. Total lipid production was taken as the response. However, it depended on the biomass directly.

\section{RESULTS AND DISCUSSION}

\section{Plackett Burman Design}

PBD was performed for identifying the significant variable among the 11 chosen variables influencing the biomass production. Pareto chart which is one of the effective tool in statistics is used to identify the significance of a factor. Fig. 1 shows the Pareto chart to understand the effects of the 11 variables on biomass production. The bar in orange colour signifies the positive effect whereas blue colour signifies the negative ef- fect. The variables $\mathrm{A}\left(\mathrm{NaHCO}_{3}\right), \mathrm{C}\left(\mathrm{NaNO}_{3}\right), \mathrm{E}(\mathrm{NaCl})$, $\mathrm{F}\left(\mathrm{MgSO}_{4} \cdot 7 \mathrm{H}_{2} \mathrm{O}\right)$ and $\mathrm{I}\left(\mathrm{KNO}_{3}\right)$ had positive effect on biomass production. On the other hand, $\mathrm{B}\left(\mathrm{K}_{2} \mathrm{HPO}_{4}\right)$, $\mathrm{D}\left(\mathrm{K}_{2} \mathrm{SO}_{4}\right), \mathrm{G}\left(\mathrm{CaCl}_{2}\right), \mathrm{H}\left(\mathrm{KH}_{2} \mathrm{PO}_{4}\right), \mathrm{J}\left(\mathrm{FeSO}_{4}\right)$ and $\mathrm{K}$ (EDTA) had negative effect on biomass production. The highest biomass concentration obtained was $1.486 \mathrm{~g} / \mathrm{L}$.

The biomass response further analysed using ANOVA (Table 3) showed that the variables A $(\mathrm{NaH}-$ $\left.\mathrm{CO}_{3}\right), \mathrm{C}\left(\mathrm{NaNO}_{3}\right)$, I $\left(\mathrm{KNO}_{3}\right)$ and $\mathrm{F}\left(\mathrm{MgSO}_{4}\right)$ had significant positive effect on biomass production implying that if these variables were used in high concentration then it would increase the production of biomass.

Although the p-value of magnesium sulphate (F) insignificant $\mathrm{p}$-value, the Pareto chart suggested that it had positive effect on biomass formation which was supported by many earlier studies. Bernard et al. (1952) reported that the effect of magnesium concentration on growth of Chlorella was predominant only at the initial stages of culture development. It was found to influence the rate of cell division and the rate of synthesis of dry matter resulting in a population of predominantly smaller cells. They also observed that as magnesium 
$\mathbf{A}$

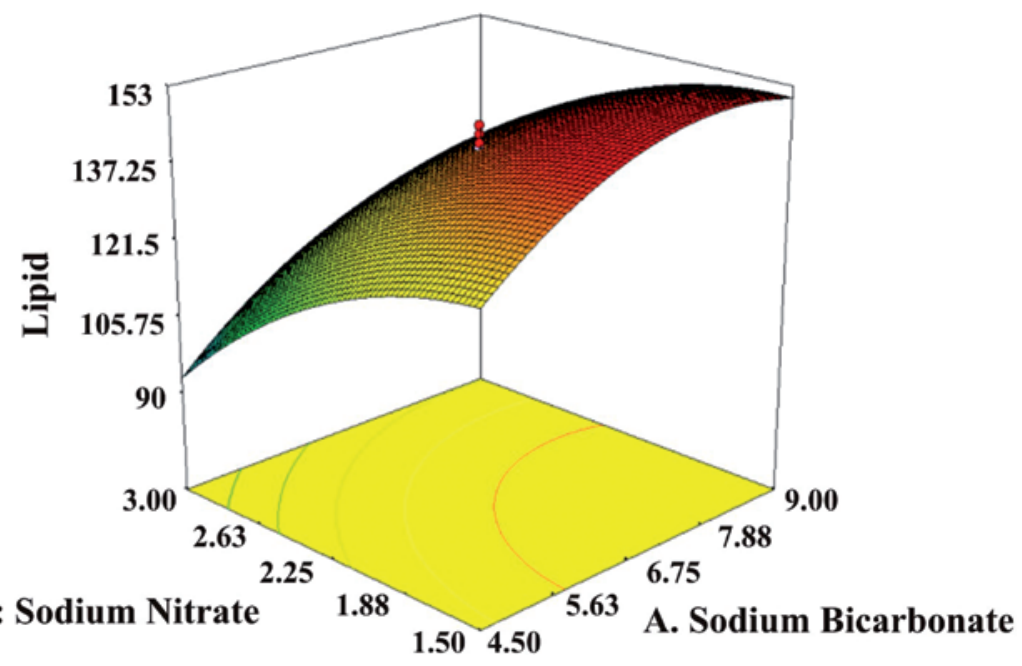

B

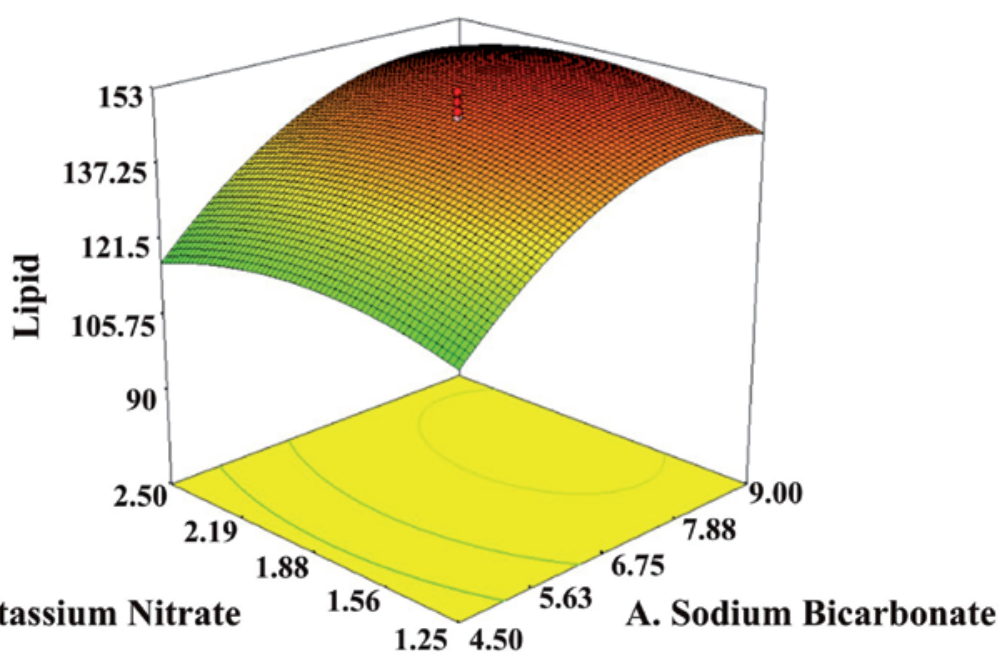

C

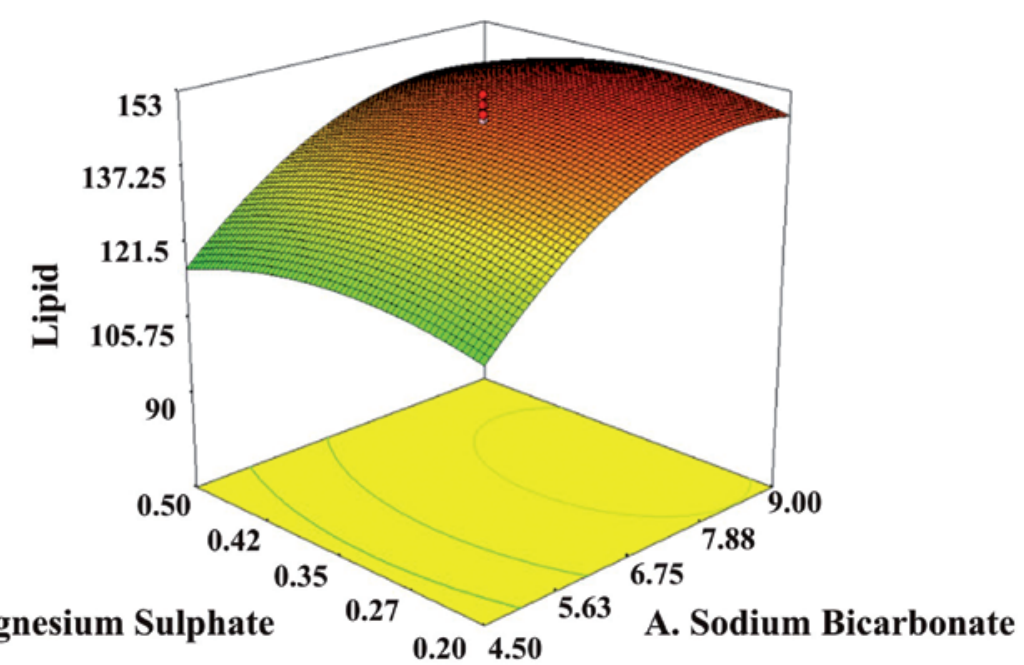

Fig. 2. $3 \mathrm{D}$ surface plot of lipid production with a function of a) $\mathrm{NaHCO}_{3}$ and $\mathrm{KNO}_{3}$ b) $\mathrm{NaHCO}_{3}$ and $\mathrm{KNO}_{3}$ c) $\mathrm{NaHCO}_{3}$ and $\mathrm{MgSO}_{4}$

The surface plot depicts the functional association of the desired response, lipid production with the screened parameters, sodium bicarbonate $(\mathrm{A})$, sodium nitrate $(\mathrm{B})$ and potassium nitrate $(\mathrm{C})$.

More precisely, the secondary interactive effects of the parameters with the desired response can be elucidated and the optimized conditions for the appropriate response (maximum) could be computed from the use of such plots. 
Table 4. Analysis of Variance on the effect of Process Parameters on Total Lipid Production

\begin{tabular}{|c|c|c|c|c|c|c|c|}
\hline S.No. & Source & Sum of Squares & Df & Mean Squares & F Value & $\begin{array}{l}\text { P-Value } \\
\text { Prob }>\text { F }\end{array}$ & Significance \\
\hline 1. & Block & 1097.27 & 2 & 548.6 & & & \\
\hline 2. & Model & 17965.2 & 14 & 1283.23 & 18.35 & $<0.0001$ & Significant \\
\hline 3. & $\mathrm{~A}-\mathrm{NaHCO}_{3}$ & 4592.7 & 1 & 4592.7 & 65.68 & $<0.0001$ & Significant \\
\hline 4. & $\mathrm{~B}-\mathrm{NaNO}_{3}$ & 8214 & 1 & 8214 & 117.48 & $<0.0001$ & Significant \\
\hline 5. & $\mathrm{C}-\mathrm{KNO}_{3}$ & 4.167 & 1 & 4.167 & 0.0595 & 0.8109 & \\
\hline 6. & $\mathrm{D}-\mathrm{MgSO}_{4} \cdot 7 \mathrm{H}_{2} \mathrm{O}$ & 88.17 & 1 & 88.17 & 1.26 & 0.282 & \\
\hline 7. & $\mathrm{AB}$ & 81 & 1 & 81 & 1.158 & 0.301 & \\
\hline 8. & $\mathrm{AC}$ & 16 & 1 & 16 & 0.229 & 0.64 & \\
\hline 9. & $\mathrm{AD}$ & 2.25 & 1 & 2.25 & 0.032 & 0.86 & \\
\hline 10. & $\mathrm{BC}$ & 64 & 1 & 64 & 0.92 & 0.356 & \\
\hline 11. & $\mathrm{BD}$ & 30.25 & 1 & 30.25 & 0.433 & 0.522 & \\
\hline 12. & $\mathrm{CD}$ & 0.25 & 1 & 0.25 & 0.0035 & 0.95 & \\
\hline 13. & $\mathrm{~A}^{2}$ & 2846.67 & 1 & 2846.67 & 40.7 & $<0.0001$ & Significant \\
\hline 14. & $\mathrm{~B}^{2}$ & 2190.96 & 1 & 2190.96 & 31.34 & $<0.0001$ & Significant \\
\hline 15. & $C^{2}$ & 848.68 & 1 & 848.68 & 12.14 & 0.004 & Significant \\
\hline 16. & $\mathrm{D}^{2}$ & 738.1 & 1 & 738.1 & 10.58 & 0.0063 & Significant \\
\hline \multirow[t]{2}{*}{17.} & Residual & 908. & 13 & 69.92 & & & \\
\hline & Lack of fit & 865.9 & 10 & 86.59 & 6.041 & 0.083 & \\
\hline
\end{tabular}

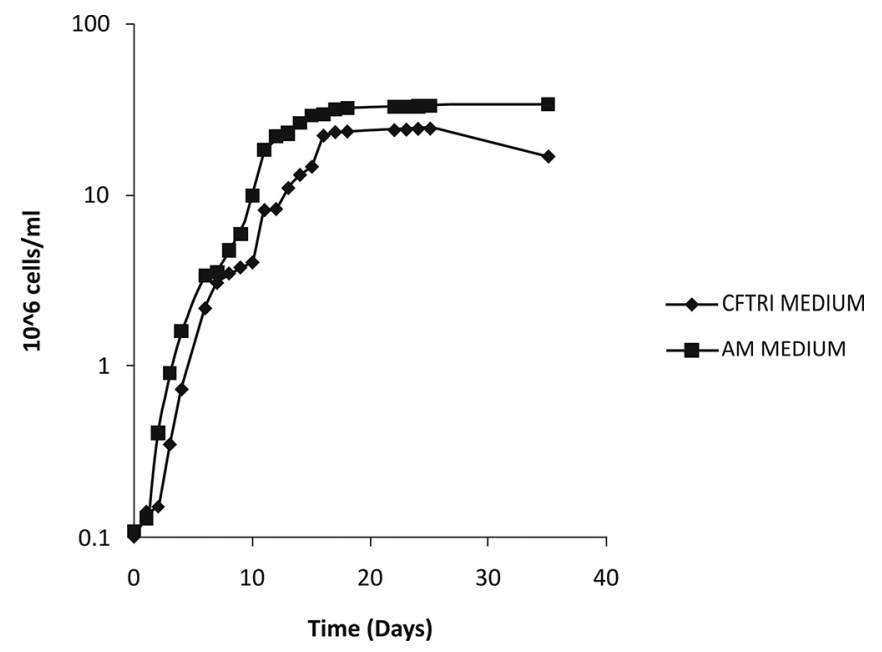

Fig. 3. Comparison of algal growth in CFTRI and AM medium

became deficient, cell division stopped even though the cell material synthesis continued at a rapid rate resulting in increase in volume of packed cells. Magnesium was found to increase both the cell density and growth.
Sodium chloride was not considered in the medium because the high concentration of $\mathrm{NaCl}$ may lead to abiotic stress. Hasegawa et al. (2000) reported the morphological, physiological and biochemical and metabolic changes due to $\mathrm{NaCl}$ related abiotic stress and the accumulation of several organic solutes and osmolytes viz proline, glycine, betaine, sugars, polyols and amino acids rather than biomass synthesis (Hoque MA et al. 2007).

\section{Central Composite Design for the production of bio- mass}

The CCD was chosen to study the interactive effect of $\mathrm{NaHCO}_{3}, \mathrm{KNO}_{3}, \mathrm{NaNO}_{3}, \mathrm{MgSO}_{4} \cdot 7 \mathrm{H}_{2} \mathrm{O}$ on the biomass and lipid production of $C$. oleofaciens.

Among the four variables chosen for $\mathrm{CCD}$, sodium bicarbonate (A) served as the carbon source. $\mathrm{CO}_{2}$ being transported through plasma membrane was incorporated in algal cells as $\mathrm{HCO}^{3-}$. Carbonic anhydrase converts $\mathrm{HCO}^{3-}$ to $\mathrm{CO}_{2}$ and the same enzyme was also responsible for the uptake of dissolved inorganic carbon (Kat- 
sunori Aizawa 1986). It was also found to have positive effect on biomass. Besides, $\mathrm{NaHCO}_{3}$ contributed to the buffering of the medium. Moreover, inorganic carbon source improved the production of chlorophyll which in turn leads to high biomass (Kong W et al. 2011). Imran Pancha et al. (2015) observed that addition of $0.6 \mathrm{~g} / \mathrm{L}$ of $\mathrm{NaHCO}_{3}$ to BG-11 medium enhanced the carbohydrate, lipid and pigment content of the microalgae Scenedesmus sp. CCNM 1077 even during nitrogen stress conditions. Cheng et al. (2009) concluded that carbon source favours the biomass and lipid synthesis.

Nitrogen limitation in the algal medium increased the lipid and triacyl glycerol content in the cells (Takagi $\mathrm{M}$ et al. 2000). Nitrogen deficiency decreased the pigment production which in turn affected the photosynthesis resulting in decrease in biomass (Piorreck M et al. 1984). Hence, to favour biomass productivity, the $\mathrm{N}$ concentration was not decreased in the optimal medium. Two sources of nitrogen viz., $\mathrm{KNO}_{3}$ and $\mathrm{NaNO}_{3}$ were considered for the study. Luveshan Ramanna et al. (2014) studied the optimization of biomass and lipid yields of Chlorella sorokiniana cultivated in domestic waste water with different nitrogen sources such as urea, sodium nitrate and ammonium nitrate. They concluded that though urea increased the biomass after day 16 , sodium nitrate steadily increased the growth until day 9 thereafter leading to death phase.

Besides serving as the sole $\mathrm{C}$ source, high carbon and nitrogen $(\mathrm{CN})$ factor plays a very important role in lipid storage and accumulation (Turcotte G et al. 1989). Low nitrogen concentration triggers lipid accumulation in the cell during the stationary phase of the growth. High $\mathrm{CN}$ ratio calls in for nitrogen deficiency in the medium. Cellular growth mainly depends on the balance between carbon and nitrogen (Giordano et al. 2014).

The responses obtained in CCD were statistically analyzed using ANOVA as shown in table 4.

The F value for all variables was found to be positive and the $p$-value of $<0.0001$ indicated that the model was significant. F value represented the relative contribution of curvature variance to residual variance. The desired large $F$ value (18.35) obtained indicated that more variance is considered in the model and further suggested that the model was significant. There is only $0.01 \%$ that such high F-value occurred due to noise. The $\mathrm{R}^{2}$ determination coefficient of the model was found to be 0.93 which indicated that $93 \%$ variability in the response can be explained by the model. And it was found to be closer to 1 . This indicated that the model was reliable for biomass and lipid production. It also signified that a good correlation between the observed and the predicted values. The linear terms A, B and the quadratic terms $\mathrm{A}^{2}, \mathrm{~B}^{2}, \mathrm{C}^{2}$ and $\mathrm{D}^{2}$ were also found to be significant. The linear terms $\mathrm{C}$ and $\mathrm{D}$ and the interacting terms $\mathrm{AB}, \mathrm{AC}, \mathrm{AD}, \mathrm{BC}, \mathrm{BD}, \mathrm{CD}$ were found insignificant as the $p$ value was found less than 0.05 . Lack of fit is an undesirable factor and value of 0.083 implied that the parameter was not significant. The coefficient of variation C.V. is $6.7 \%$ which is higher and indicated good reliability of the experimental data. Better prediction of the model was expected as the adjusted $\mathrm{R}^{2}$ value of 0.89 is close to $\mathrm{R}^{2}$ value. The adequate precision values of 12.97 shows adequate signal. The predicted response on lipid production was obtained using the following second order polynomial equation:

$$
\begin{aligned}
& \text { Lipid }=+147.33+13.83 \times \mathrm{A}-18.50 \times \mathrm{B}+0.42 \times \mathrm{C} \\
&-1.92 \times \mathrm{D}+2.25 \times \mathrm{A} \times \mathrm{B}+1.00 \times \mathrm{A} \times \mathrm{C}-0.37 \times \mathrm{A} \times \\
& \mathrm{D}+2.00 \times \mathrm{B} \times \mathrm{C}-1.37 \times \mathrm{B} \times \mathrm{D}-0.12 \times \mathrm{C} \times \mathrm{D}-10.19 \times \\
& \mathrm{A}^{2} 8.94 \times \mathrm{B}^{2}-5.56 \times \mathrm{C}^{2}-5.19 \times \mathrm{D}^{2}
\end{aligned}
$$

The response curves plotted to understand the interaction of the variables and to determine the optimum level of each variable to obtain maximum lipid are shown in the following fig. 2 (a, b, c). Maximum lipid yield of $0.78 \mathrm{~g} / \mathrm{L}$ was predicted by the model when the concentration of $\mathrm{NaHCO}_{3}, \mathrm{NaNO}_{3}, \mathrm{KNO}_{3}, \mathrm{MgSO}_{4} \cdot 7 \mathrm{H}_{2} \mathrm{O}$ were maintained at $6.75 \mathrm{~g} / \mathrm{L}, 0.75 \mathrm{~g} / \mathrm{L}, 1.88 \mathrm{~g} / \mathrm{L}$ and $0.35 \mathrm{~g} / \mathrm{L}$ respectively alongside other salts mentioned above. The novel medium developed was designated as AM medium. The concentration of $\mathrm{NaHCO}_{3}$ was increased to $6.75 \mathrm{~g} / \mathrm{L}$. Except Zarrouk medium, all the other media has less concentration of carbon compared to the optimized media. There are many studies suggesting that higher carbon content lead to increase in biomass and chlorophyll (Rekha Sharma, 2011). It was also observed that high biomass also favoured high lipid content. Biomass served as a prerequisite for the lipid production.

Fangfang Yang et al. (2014) optimized the medium consisting of $\mathrm{NaHCO}_{3}, \mathrm{NaH}_{2} \mathrm{PO}_{4} 2 \mathrm{H}_{2} \mathrm{O}$ and $\mathrm{NaNO}_{3}$ using RSM for lipid production by Scenedesmus sp. The optimal medium was found to contain $3.07 \mathrm{~g} / \mathrm{L} \mathrm{NaH}-$ $\mathrm{CO}_{3}, 15.49 \mathrm{mg} / \mathrm{L} \mathrm{NaH} \mathrm{PO}_{4} \cdot 2 \mathrm{H}_{2} \mathrm{O}$ and $803.21 \mathrm{mg} / \mathrm{L}$ $\mathrm{NaNO}_{3}$ which produced $304.02 \mathrm{mg} / \mathrm{L}$ of lipid. The interaction between the carbon and nitrogen ratio was found very good. It is also very essential to maintain the carbon nitrogen ratio of the medium. Solano et al. (2016) found that the biomass of Botryococcus braunii 
increased from 1 to $2 \mathrm{~g} / \mathrm{L}$ by adjusting the $\mathrm{C} / \mathrm{N}$ ratio using $\mathrm{Na}_{2} \mathrm{CO}_{3}$.

Jingya Li et al. (2018) concluded that low concentration $(12 \mathrm{mM})$ of $\mathrm{NaHCO}_{3}$ served as an effective carbon source for Chlorella vulgaris leading to biomass production whereas high concentration of the same at $160 \mathrm{mM}$ at a $\mathrm{pH}$ of 9.5 stimulated the lipid accumulation up to $494 \mathrm{mg} / \mathrm{L}$. The decrease in biomass was mainly due to the formation of $\left[\mathrm{HCO}_{3}^{-}\right]$which makes its utilization using the enzyme carbonic anhydrase leading to an energetically unfavourable process. Jen-Jeng Chen et al. (2014) also concluded in their full factorial experimental study that addition of $\mathrm{CO}_{2}$ was found to increase the lipid productivity, polysaccharide content and the calorific value of Chodatella sp., compared to other variables like light intensity, temperature and $\mathrm{N}_{2}$ content.

The optimal medium was found to contain only $0.75 \mathrm{~g} / \mathrm{L}$ of $\mathrm{NaNO}_{3}$. Ramírez-López et al. (2016) used a novel medium with limited nitrogen content to increase the lipid and biomass content in the algae Chlorella vulgaris UTEX 26 . It is proven that nitrogen deprivation resulted in cellular changes as follows: decrease in the cellular content of thylakoid membrane, activation acyl hydrolase and induction of phospholipid hydrolysis (Xin et al. 2010). These cumulative changes lead to an increase in intracellular fatty acid acyl-CoA. Nitrogen limitation was found to activate diacylglycerol acyltransferase which in turn converted acyl-CoA to triacylglycerides (TAGs) (Takagi et al. 2000). This resulted in increase of TAG and lipid content in the algal cell (Hu et al. 2008).

Since the growth was restricted to 8 days, it is observed that the biomass and the lipid accumulation were mainly due to the carbon utilization as the nitrates might not be depleted. It was concluded that the lipid synthesis was occurring in a stress free condition.

\section{Analysis of Lipid Production}

The lipid extracted by gravimetric method was further analysed by GC-MS to determine the total lipid content. The biomass was found to contain $34 \%$ of lipid. The order of major fatty acids present in the lipid sample was found to be $\mathrm{C} 15: 0(68.75 \%)>\mathrm{C} 18: 0$ $(26 \%)>\mathrm{C} 16: 1(4 \%)>\mathrm{C} 16: 0(0.94 \%)>\mathrm{C} 12: 0 . \mathrm{pH}$ of the medium was found to increase after the inoculation of algae. It reached around 11 on the $8^{\text {th }}$ day. Fang Yang et al. (2014) concluded that the increase in $\mathrm{pH}$ resulted neutral lipid accumulation. Olmstead et al. (2013) suggested that GL and PL were the components of cell membranes whereas NL was essential for the application of microalgae towards biodiesel and bioethanol production. NL included the fatty acid of profile $\mathrm{C} 16: 0$ to $\mathrm{C} 18: 0$ which are mainly the triacyl glycerols (Ge S. et al. 2017).

\section{Comparison between CFTRI and AM medium}

CFTRI and AM media were prepared as per the method mentioned in material and methods. Both culture media were compared for the growth of the algae by inoculating the same number of cells $\left(1 \times 10^{5}\right.$ cells/ $\mathrm{ml}$ ) in $100 \mathrm{ml}$ of CFTRI and AM medium. Growth was continuously monitored by counting the cells using haemocytometer and the growth curve was plotted as shown in fig. 3. The maximum cell count was observed as 250 cells $/ \mathrm{ml}$ in CFTRI medium on $25^{\text {th }}$ day and 342 cells $/ \mathrm{ml}$ in AM medium on $35^{\text {th }}$ day.

The growth in CFTRI medium was retarded after 16th day and thereafter it entered the stationary phase. Though the growth continued in AM medium even after $25^{\text {th }}$ day and reached maximum on $35^{\text {th }}$ day, the cells entered stationary phase on the $16^{\text {th }}$ day similar to CFTRI medium. The higher cell number in the AM medium is due to the greater number of cell divisions. This may be attributed to the additional growth promoting substance (Potassium nitrate) present in the composition of AM medium (Hare PD et al. 1998). The optimal medium was compared with CFTRI medium and it produced biomass 3 times more than the CFTRI medium. The optimal media developed by Kuan-Chen Cheng et al. (2013) containing $\mathrm{NaNO}_{3}$ and $\mathrm{MgSO}_{4} \cdot 7 \mathrm{H}_{2} \mathrm{O}$ could produce only 1.8 times higher than the original proteose medium. Growth rate of the algae in AM medium was also higher compared to the CFTRI medium. It was found to be 0.19 day $^{-1}$ in CFTRI medium whereas $\mu$ in AM medium was found to be 0.14 day $^{-1}$. The biomass was weighed on the $15^{\text {th }}$ day for both the media. The biomass produced by CFTRI was found to be $600 \mathrm{mg} / \mathrm{L}$ whereas AM medium produced a biomass around 1650 $\mathrm{mg} / \mathrm{L}$ which was almost 2.7 times more than the CFTRI media.

\section{CONCLUSION}

The Plackett Burman design was used to determine the effective variables of a culture medium which can produce high biomass. Among the 11 variables tested, the four variables $\mathrm{NaHCO}_{3}, \mathrm{NaNO}_{3}, \mathrm{KNO}_{3}$, $\mathrm{MgSO}_{4} \cdot 7 \mathrm{H}_{2} \mathrm{O}$ were found to highly influence the bio- 
mass production. These effective variables were further optimized using response surface methodology. The optimal medium composition was found to be $6.75 \mathrm{~g} / \mathrm{L}, 0.75 \mathrm{~g} / \mathrm{L}, 1.88 \mathrm{~g} / \mathrm{L}$ and $0.35 \mathrm{~g} / \mathrm{L}$ for $\mathrm{NaHCO}_{3}$, $\mathrm{NaNO}_{3}, \mathrm{KNO}_{3}, \mathrm{MgSO}_{4} \cdot 7 \mathrm{H}_{2} \mathrm{O}$ variables respectively. The experimental value $(0.74 \mathrm{~g} / \mathrm{L})$ was very close to the predicted value $(0.78 \mathrm{~g} / \mathrm{L})$. In the present study, the new medium composition arrived for the cultivation of C. oleofaciens was compared with the CFTRI medium. These results clearly indicated that the AM medium (present study) is an effective medium towards the high biomass and lipid production. The biomass in AM medium was found to be 3 times more than that of the CFTRI medium. The growth rate of AM medium was also 1.35 times greater than the CFTRI medium. Fatty acids produced by the C. oleofaciens in AM medium suggested that it is suitable for biofuel studies owing to the higher proportion of saturated fatty acids. Optimization of medium composition for different microalgae is very necessary to improve the biomass and lipid content. The medium compositions arrived in the present study for the C. oleofaciens suggests that this is a promising medium to improve the concepts of the microalgal biomass and biodiesel production.

\section{REFERENCES}

Allen M. M., Stanier R. Y. (1968) Growth and division of some unicellular blue-green algae. J. Gen. Microbiol. 51: 199-202

Aizawa K., Miyachi S. (1986) Carbonic anhydrase and $\mathrm{CO}_{2}$ concentrating mechanisms in microalgae and cyanobacteria. FEMS Microbiology Reviews. 2: 215-233

Andrés F. Barajas-Solano, Guzmán-Monsalve A., Viatcheslav Kafarov (2016) Effect of Carbon-Nitrogen Ratio for the Biomass Production, Hydrocarbons and Lipids on Botryoccus braunii UIS 003. Chem. Engg. Transactions. 49: 247-252

Bernard J., Finkle, Appleman D. (1952) The effect of magnesium concentration on growth of Chlorella. Plant Physiol. 28: 664 673

Bischoff H. W., Bold H. C. (1963) Phycological Studies IV: Some soil algae from Enchanted Rock and related algal species. Univ Texas Publ. pp. 6318: 1-95

Cheng Y., Lu Y., Gao C., Wu Q. (2009) Alga-based biodiesel production and optimization using sugar cane as the feedstock. Energy Fuels 23: 4166-4173

Cho H. U., Kim Y. M., Choi Y. N., Xu X., Shin D. Y., Park J. M. (2015) Effects of $\mathrm{pH}$ control and concentration on microbial oil production from Chlorella vulgaris cultivated in the effluent of a low-cost organic waste fermentation system producing volatile fatty acids. Bioresour. Technol. 184: 245-250

Franklin S.E., Mayfield S.P. (2004) Prospects for molecular farming in the green alga Chlamydomonas reinhardtii. Curr. Opin. Plant Bio. 7:150-165

Ge S., Champagne P., Plaxton W. C., Leite G. B., Marazzi F. (2017) Microalgal cultivation with waste streams and metabolic con- straints to triacylglycerides accumulation for biofuel production. Biofuels, Bioproducts and Biorefining 11: 325-343

Ghirardi M. L., Zhang L., Lee J. W., Flynn T., Seibert M., Greenbaum E., Melis A. (2000) Microalgae: a green source of renewable hydrogen. Trends Biotechnol. 18: 506-511

Golueke C. G., Oswald W. J., Gotaas H. B. (1957) Anaerobic digestion of algae. Appl. Microbiol. 5: 47-55

Guillard R. R., Ryther J. H. (1962) Studies on marine planktonic diatoms I. Cyclotella nana Hustedt and Detonula confervacea (Cleve). Gran. Can. J. of Microbiol. 8: 229-239

Gutierrez L. F., Ratti C., Belkacemi K. (2008) Effects of drying method on the extraction yields and quality of oils from Quebec Sea buckthorn (Hippophae rhamnoides L.) seeds and pulp. Food Chem. 106: 896-904

Hare P. D., Cress W. A., Van-staden J. (1998) Dissecting the roles of osmolyte accumulation during stress. Plant Cell. Environ. 21: 535-554

Hasegawa P. M., Bressan R. A., Zhu J. K., Bohnert H. J. (2000) Plant cellular and molecular response to high salinity. Physiol Plant Mol. Biol. 51: 463-499

Hoque M. A., Okuma E., Banu M. N. A., Nakamura Y., Shimoishi Y., Murata Y. (2007) Exogenous proline mitigates the detrimental effects of salt stress more than the betaine by increasing antioxidant enzyme activities. J. Plant Physiol. 164: 553-561

Hu Q., Sommerfeld M., Jarvis E., Ghirardi M., Posewitz M., Seibert M., Darzins A. (2008) Microalgal triacylglycerols as feedstocks for biofuel production: perspectives and advances. The Plant $J$. 54: 621-639

$\mathrm{Hu}$ Q., Sommerfeld M., Jarvis E., Ghirardi M., Posewitz M., Seibert M., Darzins A. Illman M., Scragg A. H., Shales S. W. (2000) Increase in Chlorella Strains Calorific Values when Grown in Low Nitrogen Medium. Enz. and Microbial. Technol.27: 631-635

Imran P., Kaumeel C., Tonmoy G., Chetan P., Rahulkumar M., Sandhya M. (2015) Bicarbonate supplementation enhanced biofuel production potential as well as nutritional stress mitigation in the microalgae Scenedesmus sp. CCNM 1077. Bioresour. Technol. 193: 315-323

Jeng Chen J., Li Y., Lai W. (2014) Application of experimental design methodology for optimization of biofuel production from microalgae. Biomass and Bioenergy 64: 11-19.

Jingya L., Changhao L., Christopher Q. Lan, Dankui L. (2018) Effects of sodium bicarbonate on cell growth, lipid accumulation, and morphology of Chlorella vulgaris. Microb. Cell Fact. 17: 111-121

Kandhro A., Sherazi S. T. H., Mahesar S. A., Bhanger M. I., Younis T. M., Rauf A. (2008) GC-MS quantification of fatty acid profile including trans FA in the locally manufactured margarines of Pakistan. Food Chem.109: 207-211

Kong W., Song H., Cao Y., Yang H., Hua S., Xia C. (2011) The characteristic of biomass production, lipid accumulation and chlorophyll biosynthesis of Chlorella vulgaris under mixotrophic cultivation. Afr. J. Biotechnol. 10: 11620-11630

Kuan Chen C., Ming R., Kimberly L. Ogden (2013) Statistical optimization of culture media for growth and lipid production of Chlorella protothecoides UTEX 250. Bioresor. Technol 128: 44-48

Liu Z. L., Saha B. C., Slininger P. J. (2008) Lignocellulosic biomass conversion to ethanol by Saccharomyces In: Bioenergy, ASM Press, Washington, DC. 17-36

Liu Huang J., Sun Z. (2011) Differential lipid and fatty acid profiles of photoautotrophic and heterotrophic Chlorella zofingiensis: 
assessment of algal oils for biodiesel production. Bioresour. Technol. 102: 106-110

Luveshan R., Abhishek G., Ismail R., Faizal B (2014) The optimization of biomass and lipid yields of Chlorella sorokiniana when using wastewater supplemented with different nitrogen sources. Bioresource Technol. 168: 127-135

Marchetti J. M., Miguel V. U., Errazu A. F. (2007) Possible Methods For Biodiesel Production. Renew. Sus. Energy Rev. 11: 1300 1311

Martinez M. R., Chakroff R. P., Pantastico J. B. (1975) Direct phytoplankton counting techniques. Philippine agriculturist. 59: $43-50$

Olmstead I. L., Hill D. R., Dias D. A., Jayasinghe N. S., Callahan D. L., Kentish S. E., Martin G. J. (2013) A quantitative analysis of microalgal lipids for optimization of biodiesel and omega-3 production. Biotechnol. Bioeng. 110: 2096-2104

Pablo C. Giordano, Alejandro J. Beccaria, Héctor C. Goicoechea. (2014) Rational design of a culture medium for the intensification of lipid storage in Chlorella sp. Performance evaluation in air-lift bioreactor. Bioresour. Technol. 158: 269-277

Piorreck M., Baasch K.H., Pohl P. (1984) Biomass Production, Total Protein, Chlorophylls, Lipids and Fatty Acids of Fresh Water Green and Blue-Green Algae under Different Nitrogen Regimes. Phytochem. 23: 207-216

Plackett R.L., Burman J.P. (1946) The design of optimum multifactorial experiments. Biometrika 33: 305-325

Ramírez López C., Chairez I., Fernández Linares L. (2016) A novel culture medium designed for the simultaneous enhancement of biomass and lipid production by Chlorella vulgaris UTEX 26. Bioresour. Technol. 212: 207-216

Rodriguez A. (2011) Enhancement of Lutein Production in Chlorella sorokiniana (chorophyta) by improvement of culture conditions and random mutagenesis. Mar. Drugs 9: 1607-1624

Rekha S., Gajendra P. Singh, Vijendra K. Sharma (2011) Comparison of Different Media Formulations on Growth, Morphology and Chlorophyll Content of Green Alga, Chlorella Vulgaris. Intl. J. of Pharma and Bio Sciences. 2: 506-516

Sivaramakrishnan R., Incharoensakdi A. (2018) Utilization of microalgae feedstock for concomitant production of bioethanol and biodiesel. Fuel 217: 458-466

Sivaramakrishnan R., Incharoensakdi A. (2017) Production of methyl ester from two microalgae by two-step transesterification and direct transesterification. Environ. Sci. Pollut. Res. 24: 4950-4963

Shay E.G. (1993) Diesel fuel from vegetable oils: Status and Opportunities. Biomass Bioenergy 4: 227-242
Stein J (ED.) (1973) Handbook of Phycological methods. Culture methods and growth measurements. Cambridge University Press. 448 pp.

Takagi M., Watanabe K., Yamaberi K., Yoshida Y. (2000) Limited feeding of potassium nitrate for intracellular lipid and triglyceride accumulation of Nannochloris sp. UTEX LB1999. Appl. Microbiol. Biotechnol. 54: 112-117

Tiwari K., Kumar A., Raheman H. (2007) Biodiesel production from Jatropha curcas with high free fatty acids: an optimized process. Biomass Bioenergy 31: 569-575

Tornabene T. G., Holzer G., Lien S., Burris N. (1983) Lipid Composition Of The Nitrogen Starved Green Alga Neochloris oleoabundans. Enzyme Microb. Technol. 5: 435-440

Turcotte, G., Kosaric, N. (1989) The effect of C/N ratio on lipid production by Rhodosporidium toruloides ATCC 10788. Biotechnol. Lett. 9: 637-642

Van der Laaka W. W. M., Raven R. P. J. M., Verbong G. P. J. (2007) Strategic Niche Management for Biofuels: Analysing Past Experiments for Developing New Biofuel Policies. Energy Policy 35: 3213-3225

Venkatraman L. V., Becker E. W. (1985) Biotechnology and utilization of algae - The Indian experience. Central Food Technological Research Institute, Mysore, India. WalneP.R. (1970)

Studies on the food value of nineteen genera of algae to juvenile bivalves of the genera Ostrea, Crassostrea, Mercenaria, and Mytilis. Fish. Invest. 26: 162

Wu Q., Miao X. (2006) Biodiesel production from heterotrophic microalgal oil. Bioresour. Technol. 97: 841-846

Xin L., Hong-ying H., Ke G., Ying-xue S. (2010) Effects of different nitrogen and phosphorus concentrations on the growth, nutrient uptake, and lipid accumulation of a freshwater microalga Scenedesmus sp. Bioresour. Technol. 101: 5494-5500

Xiong W., Chunfang G., Dong Y., Chao W., Qingyu W. (2010) Double $\mathrm{CO}_{2}$ fixation in photosynthesis-fermentation model enhances algal lipid synthesis for biodiesel production. Bioresour. Technol. 101: 2287-2293

Yang F., Long L., Sun X., Wu H., Li T., Xiang W. (2014) Optimization of Medium Using Response Surface Methodology for Lipid Production by Scenedesmus sp. Mar. Drugs. 12: 1245-1257

Zarrouk C. (1966) Contribution a l'étude du cyanophycée. Influence de divers facteurs physiques et chimiques sur la croissance et la photosynthèse de spirulina maxima (setch et gardner) geitl. paris: Faculte des Sciences, Universite de Paris.

Received on $10^{\text {th }}$ April, 2019; revised on $7^{\text {th }}$ June, 2019; accepted on $20^{\text {th }}$ June, 2019 